\title{
フェンスによる貯水池潜入密度流の流動制御 CONTROL OF PLUNGE FLOWS IN A RESERVOIR BY A FENCE
}

\author{
秋山 壽一郎 ${ }^{1}$ - 重枝 未玲 ${ }^{2} \cdot$ 安藤 $^{\text {祐馬 }}{ }^{3}$ - 小野 修平 ${ }^{4}$ - 小川 真由子 ${ }^{4}$ \\ Juichiro AKIYAMA, Mirei SIGE-EDA,Yuma ANDO, Shuhei ONO and Mayuko OGAWA \\ ${ }^{1}$ フェロー会員 Ph.D. 九州工業大学教授 工学部建設社会工学科（†804-8550北九州市戸烟区仙水町1-1） \\ ${ }^{2}$ 正会員 博士（工学） 九州工業大学助教授 工学部建設社会工学科（同上）

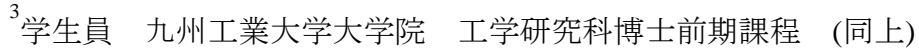 \\ 4学生員 九州工業大学 工学部建設社会工学科 (同上)
}

\begin{abstract}
Control of plunge flows in a reservoir by a fence, as a countermeasure for fresh red tide bloom, is investigated experimentally and numerically. It is found from the experiments for a well-mixed reservoir that the submerged depth and position of a fence, to reduce effectively the layer thickness of inflowing water behind a fence as well as the amount of mixing, are identified. A numerical model, based on the SMAC and MUSCL method with use of the collocated grid in general-coordinate system, is used to reproduce the experimental results and to examine the effectiveness of a fence in a stratified reservoir via numerical experiments. It is demonstrated that the model is a useful tool to determine the submerged depth and position of a fence in both a well mixed and stratified reservoir.
\end{abstract}

Key Words: reservoir, plunge flow, algal blooming, fence, experiment, numerical model

\section{1.はじめに}

ダム貯水池は，水資源，親水空間，生態系の生息 環境などの多様な機能を有しているが，閉鎖性水域 という污濁物質が蓄積しやすい性質に加え, 非特定 污染源等からの污濁負荷の増大に伴い，近年，そこ での水環境が大きく損なわれてきている。このため, 改善に向けた速やかな取組みが求められている。水 環境の改善を図るためには，流域管理が抜本的であ るが，一方でこれまで以上に効果的な池内詨策を講 じることも極めて重要である.

池内対策には曝気による強制循環, 選択流入施設 やフェンスを用いた流動制御などがある。本研究で 対象とするフェンスには，富栄養化によって増殖し た藻類が水域全体へ拡がることを防止するだけでな く, 溶存リン・窒素を含む流入水をより深い水域に 強制的に潜り込ませることで, 藻類の光合成を減少 させ増殖を抑制する働きがある。従って，フェンス を用いた池内対策では, 流入によってもたらされた 栄養塩の水域への拡散を抑制し, 流入水をより深く 潜り込ませるとともに，栄養塩を池内に滞留させる ことなく速やかに放流・排除できるように流動制御 することが求められる。しかし，そのような流動制 御を効果的に行えるようなフェンス設置法について はほとんどわかっていない。

河川水とともに流入した栄養塩等の物質は，曝気 等の人為的操作を行わない自然の状態では，風の影
響や水温差・懸濁物質による密度差に起因した流動 現象の影響を強く受ける。このため，フェンスを用 いた流動制御では，そこで生じる密度流現象の把握 が不可欠となる。特に, 潜入密度流は赤潮物質の集 積機構や流入濁水の挙動等の貯水池における様々な 水質問題と深く関わっていることから, 潜入密度流 との関係において淡水赤潮に関する数多くの研究が これまでなされてきた。例えば, 久保ら ${ }^{1)}$, 畑 ${ }^{2)}$, 中 本 $^{3)}$, 山田 $5^{4)}$, 松尾 $5^{5)}$, 天野ら ${ }^{6)}$, 秋山ら ${ }^{7), 8)}$ な゙ により, 現地観測や室内実験等を通じ調べられてい る。また, 潜入密度流そのものについても, 理論解

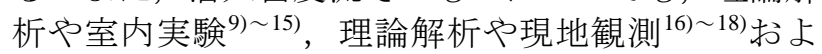
び数值解析 ${ }^{19)}$ 22) を通じて数多くの研究が重ねられ ている。しかしながら, 潜入密度流は流入条件や貯 水池形状の影響を受けるため ${ }^{23)}$, 潜入点の予測すら 十分な精度で行えないのが原状である ${ }^{24)}$. 実水域で は流入条件も変動するので, その予測はより難しい. 以上のように, 実水域での自然な潜り込み(潜入 密度流)は, 流入条件や貯水池形状等の固有の条件 の影響を受ける。さらに，フェンスを用いた強制的 な潜り込み(流動制御)では，さらにフェンスの設置 条件の影響を受けることとなる。このような理由で， 効果的な流動制御が可能となるフェンスの設置法に ついて一律かつ普遍的な基準を得ることは難しいと 考えられることから， ダム貯水池での流動現象を十 分な精度で再現できるとともに, 池内対策を検討で きる手段の確立が強く望まれる。 
表-1 実験条件と実験結果

\begin{tabular}{|c|c|c|c|c|c|c|c|c|c|c|c|}
\hline \multirow{2}{*}{ CASE } & \multirow{2}{*}{$\begin{array}{c}\mathrm{q}_{0} \\
\left(\mathrm{~cm}^{2} / \mathrm{s}\right)\end{array}$} & \multirow{2}{*}{$\mathrm{F}_{0}$} & \multirow{2}{*}{$\begin{array}{c}\mathrm{h}_{\mathrm{c}} \\
(\mathrm{cm})\end{array}$} & \multirow{2}{*}{$\mathrm{x}_{\mathrm{f}} / \mathrm{L}$} & \multirow{2}{*}{$\mathrm{Z}_{\mathrm{f}} \mathrm{h}_{\mathrm{c}}$} & \multicolumn{2}{|c|}{$\mathrm{h}_{\mathrm{h}} / \mathrm{h}_{\mathrm{c}}$} & \multirow{2}{*}{$\Delta / h_{c}$} & \multirow{2}{*}{$\gamma_{\mathrm{s}}$} & \multirow{2}{*}{$\gamma_{\mathrm{h}}$} & \multirow{2}{*}{$\gamma_{t}$} \\
\hline & & & & & & M界面 & 目視界面 & & & & \\
\hline A-1 & \multirow{5}{*}{8.5} & \multirow{5}{*}{2.43} & \multirow{5}{*}{4.5} & \multirow{5}{*}{0.675} & - & 2.50 & 3.09 & - & - & - & 0.584 \\
\hline A-2 & & & & & 3.89 & 2.23 & 2.65 & 0.5 & - & - & 0.489 \\
\hline A-3 & & & & & 3.39 & 2.07 & 2.53 & 0 & - & - & 0.290 \\
\hline A-4 & & & & & 2.89 & 2.05 & 2.21 & -0.5 & - & - & 0.282 \\
\hline A-5 & & & & & 2.19 & 2.37 & 2.68 & -1.2 & - & - & 0.336 \\
\hline B-1 & 6.5 & 1.86 & 3.8 & - & - & 2.82 & 3.43 & - & 0.460 & 0.190 & 0.651 \\
\hline B-2 & 8.5 & 2.43 & 4.5 & - & - & 2.50 & 3.09 & - & 0.432 & 0.106 & 0.584 \\
\hline B-3 & 11.5 & 3.29 & 5.5 & - & - & 2.19 & 2.57 & - & 0.303 & 0.042 & 0.357 \\
\hline C-1-1 & \multirow{2}{*}{6.5} & \multirow{2}{*}{1.86} & \multirow{2}{*}{3.8} & 0.450 & 4.08 & 2.72 & 3.00 & \multirow{6}{*}{-0.5} & 0.324 & 0.022 & 0.346 \\
\hline C-1-2 & & & & 0.675 & 3.42 & 2.12 & 2.56 & & 0.230 & 0.057 & 0.299 \\
\hline C-2-1 & \multirow{2}{*}{8.5} & \multirow{2}{*}{2.43} & \multirow{2}{*}{4.5} & 0.450 & 3.22 & 2.47 & 2.77 & & 0.296 & 0.020 & 0.323 \\
\hline C-2-2 & & & & 0.675 & 2.89 & 2.05 & 2.21 & & 0.224 & 0.047 & 0.282 \\
\hline C-3-1 & \multirow{2}{*}{11.5} & \multirow{2}{*}{3.29} & \multirow{2}{*}{5.5} & 0.450 & 2.64 & 2.11 & 2.45 & & 0.322 & 0.062 & 0.405 \\
\hline C-3-2 & & & & 0.675 & 2.45 & 1.73 & 2.18 & & 0.153 & 0.049 & 0.210 \\
\hline D-1-1 & \multirow{2}{*}{6.5} & \multirow{2}{*}{1.86} & \multirow{2}{*}{3.8} & 0.450 & 4.58 & 2.34 & 2.76 & \multirow{6}{*}{0} & 0.301 & 0.023 & 0.331 \\
\hline D-1-2 & & & & 0.675 & 3.92 & 2.23 & 2.68 & & 0.253 & 0.057 & 0.324 \\
\hline D-2-1 & \multirow{2}{*}{8.5} & \multirow{2}{*}{2.43} & \multirow{2}{*}{4.5} & 0.450 & 3.72 & 2.18 & 2.73 & & 0.288 & 0.016 & 0.309 \\
\hline D-2-2 & & & & 0.675 & 3.39 & 2.07 & 2.53 & & 0.234 & 0.046 & 0.290 \\
\hline D-3-1 & 115 & 320 & 55 & 0.450 & 3.14 & 1.91 & 2.33 & & 0.285 & 0.009 & 0.296 \\
\hline D-3-2 & 11.5 & 0.29 & J.J & 0.675 & 2.95 & 1.89 & 2.31 & & 0.165 & 0.054 & 0.228 \\
\hline
\end{tabular}

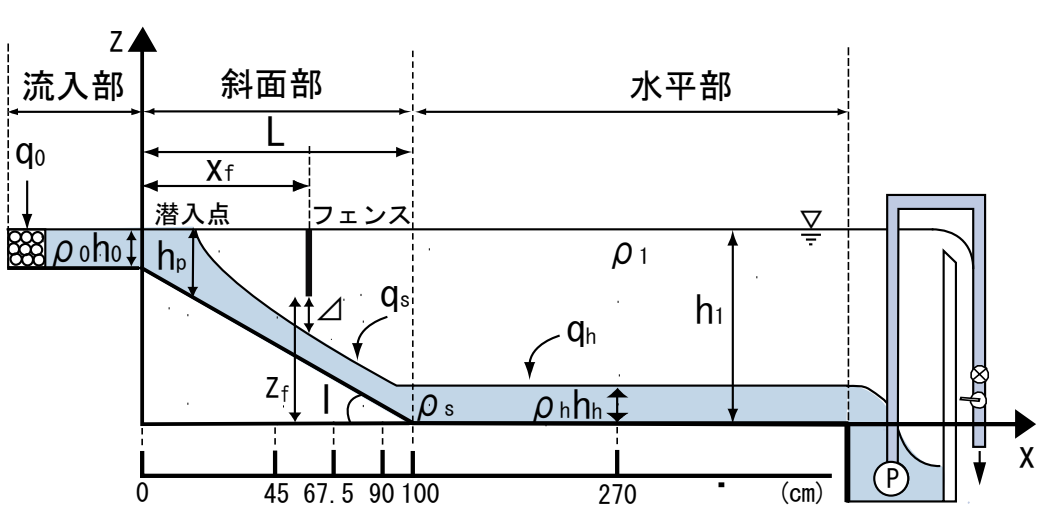

図-1 実験装置の概要と重要な諸量

表-2 パラメータの定義

\begin{tabular}{|ll|}
\hline $\mathrm{F}_{0}$ & $:$ 流入内部 Froude 数 $\left(=\mathrm{q}_{0} /\left(\varepsilon_{0} \mathrm{gh}_{0}{ }^{3}\right)^{1 / 2}\right)$ \\
$\mathrm{g}$ & $:$ 重力加速度 \\
$\mathrm{h}_{\mathrm{c}}$ & $:$ 流入条件に基づく内部限界水深 $\left(=\left(\mathrm{q}_{0}{ }^{2} / \varepsilon_{0} \mathrm{~g}\right)^{1 / 3}\right)$ \\
$\mathrm{x}_{\mathrm{f}}$ & $:$ フンスの設置位置 $($ 流入点からフェンスまでの距離 $)$ \\
$\mathrm{z}_{\mathrm{f}}$ & $:$ 設置水深 $($ 基淮線からフェンス下端までの距離 $)$ \\
$\gamma_{\mathrm{h}}$ & $:$ 水平部の混合率 $\left(=\varepsilon_{\mathrm{s}} / \varepsilon_{\mathrm{h}}-1\right)$ \\
$\gamma_{\mathrm{s}}$ & $:$ 斜面下端の混合率 $\left(=\varepsilon_{0} / \varepsilon_{\mathrm{s}}-1\right)$ \\
$\gamma_{\mathrm{t}}$ & $:$ 総混合率 $\left(=\varepsilon_{0} / \varepsilon_{\mathrm{h}}-1\right)$ \\
$\varepsilon_{0}$ & $:$ 流入水の相対密度差 $\left(=\left(\rho_{0}-\rho_{1}\right) / \rho_{1}\right)$ \\
$\varepsilon_{\mathrm{h}}$ & $:$ 水平部下流での相対密度差 $\left(=\left(\rho_{\mathrm{h}}-\rho_{1}\right) / \rho_{1}\right)$ \\
$\varepsilon_{\mathrm{s}}$ & $:$ 斜面下端での相対密度差 $\left(=\left(\rho_{\mathrm{s}}-\rho_{1}\right) / \rho_{1}\right)$ \\
$\Delta$ & $:$ 自然な潜り込み状態での界面を基淮とした時のフェンス \\
& 下端までの距離 \\
\end{tabular}

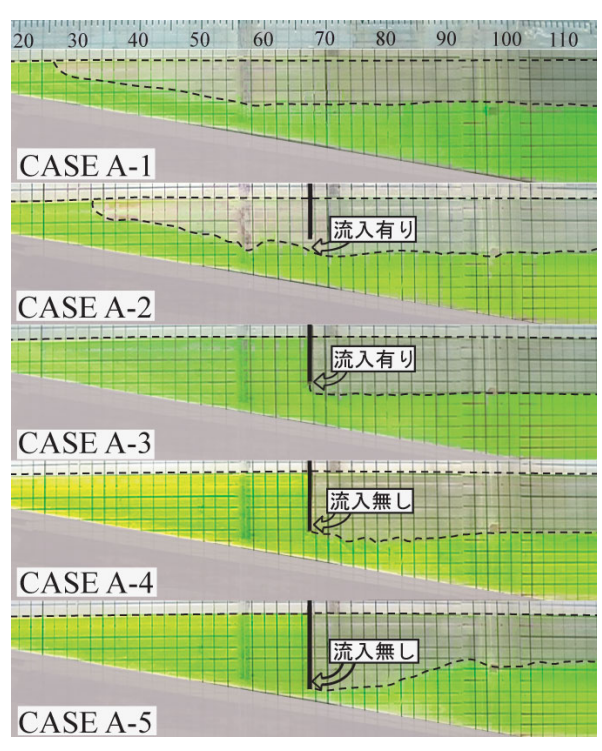

図-2 フェンス設置水深と流況 (CASE A)

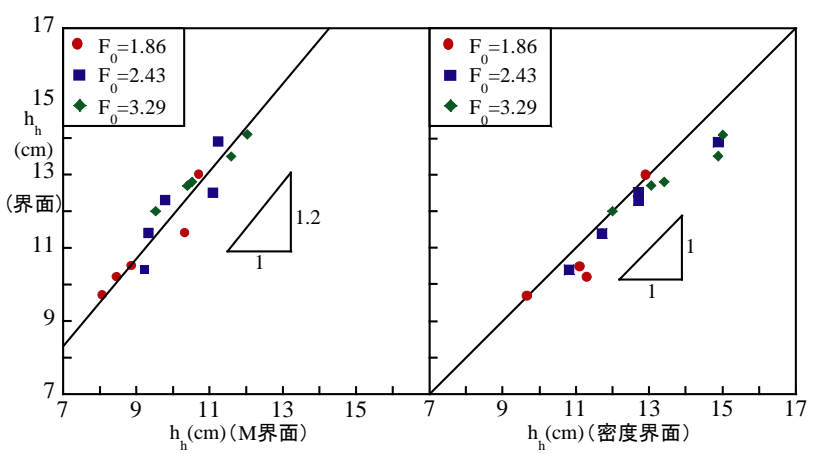

図-3 界面と $\mathrm{M}$ 界面(左)および界面と密度界面(右) 

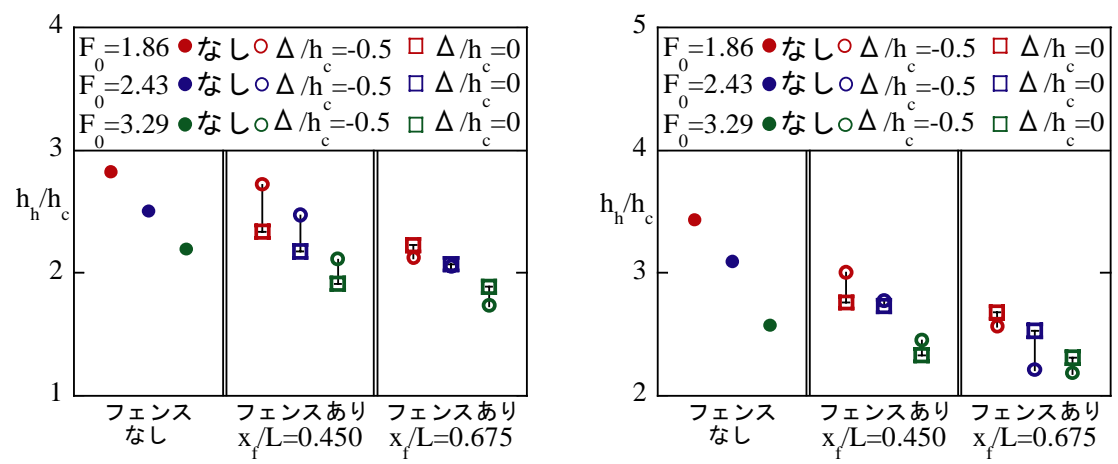

図-4 水平部での層厚（左：M界面，右：界面）

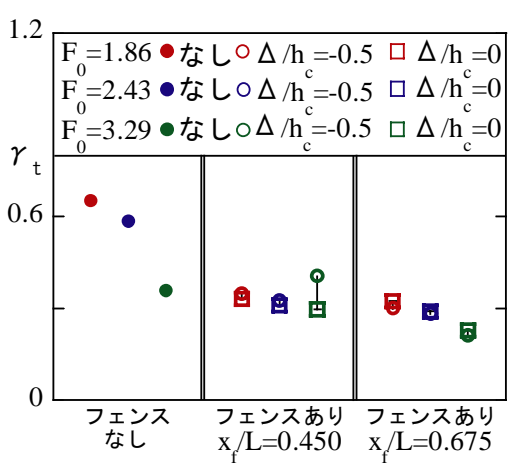

図-5 水平部での総混合率
本研究は, 以上のような背景を踏まえ, 平水時の 定常流を想定して，(1)室内実験に基づき，フェンス を設置しない自然な潜り込みに比して, 流入水の混 合および下層流の層厚が小さくなるような強制的な 潜り込みを促進できるようなフェンスの設置法に関 する指標を得た上で，(2)数值シミュレーションを用 いた効果的なフェンス設置法の確立を目的として, 著者らが開発した貯水池流動モデル(SMM-BIF-CG model $)^{22)}$ に基づき, フェンスによる潜入密度流の流 動制御の再現を試みるとともに，(3)数值実験により， 潜入から中層密度流として躍層に貫入する状況での フェンスの設置効果について調べたものである.

\section{2. 実験}

実験装置は，流入部(長さ $100 \mathrm{~cm}$, 水深 $\left.\mathrm{h}_{0}=2.5 \mathrm{~cm}\right)$, 斜面部(長さ $\mathrm{L}=100 \mathrm{~cm}$, 勾配 $\mathrm{I}=1 / 5$ ) および水平部(長 さ345cm, 高さ $38 \mathrm{~cm})$ のアクリル製水槽である. 水 槽中に水深 $\mathrm{h}_{1}=22.5 \mathrm{~cm}$ まで淡水(密度 $\rho_{1}$ ) を貯留した後 に, 流入部からウラニンで着色した塩水(密度 $\rho_{0}$, 単 位幅流量 $\mathrm{q}_{0}$ )を流入させ, 自然な潜り込み状態での潜 入密度流を発生させた。 なお，下流端に設けられた 越流堰により水深 $\mathrm{h}_{1}$ は一定に保たれている。図-1に 装置の概要と重要な諸量を示す.

フェンスが設置された状態での流動状況は，与え られた貯水池形状において, 流入内部Froude数 $\mathrm{F}_{0}$, 無次元の設置位置 $\mathrm{x}_{\mathrm{f}} / \mathrm{L}$ 設置水深 $\mathrm{z}_{\mathrm{f}} / \mathrm{h}_{\mathrm{c}}$ およびフェン スの設置状況(設置数, 設置間隔)によって異なって くる.このように，対象とする現象を規定する要因 が多いので，フェンスは1枚設置とし，CASE A〜 CASE Dの4ケースの実験を行い, 効果的な流動制御 が可能となるフェンスの設置法について基礎的な知 見を得た。表-1に実験条件，表-2に重要なパラメー 夕をまとめて示す。なお，表-1中には実験結果も併 せて示してある. 同表において, 水平部での無次元 層厚 $\mathrm{h}_{\mathrm{h}} / \mathrm{h}_{\mathrm{c}}$ と総混合率 $\gamma_{\mathrm{t}}$ が，フェンスを設置しない自 然な潜り込み状態での值に比して小さくなることが, フェンスの設置効果の指標となる.

CASE Aでは，自然な潜り込み状態での目視界面 （以下，目視界面を「界面」という）を基準として， $\mathrm{Z}_{\mathrm{f}} / \mathrm{h}_{\mathrm{c}}$ を4通りに変化させ，その影響について調べた。 CASE Bでは， $\mathrm{F}_{0}$ を通りに変化させ，自然な潜り込 み状態について調べた. CASE C とCASE Dでは,
CASE Aよりフェンスの設置効果が大きいと認めら れた $\Delta / \mathrm{h}_{\mathrm{c}}=-0.5$ (界面下方) と0(界面位置)について, $\mathrm{z}_{\mathrm{f}} / \mathrm{h}_{\mathrm{c}}$ を一定に保った状態でCASE B 同一流入条件下 でフェンスの設置位置を $\mathrm{x}_{\mathrm{f}} / \mathrm{L}=0.45$ あいは 0.675 の 2 通りに変化させ，その影響について調べた。

測定および解析方法については，(1)全CASEで目 視界面の決定と画像解析による流動状況(潜入開始 から定常状態に達するまで)の把握，(2) CASE Bでは 定常状態での斜面部 $(\mathrm{x}=45,67.5,90 \mathrm{~cm})$ と水平部 $(\mathrm{x}=270 \mathrm{~cm})$, CASE A, CASE CおよびCASE Dでは斜 面部 $(x=100 \mathrm{~cm})$ と水平部 $(x=270 \mathrm{~cm})$ での流動層の密度 ならびに流速分布の把握である. 斜面部の層平均水 理量(層厚 $\mathrm{h}_{\mathrm{s}}$, 流速 $\mathrm{U}_{\mathrm{s}}$, 相対密度差 $\varepsilon_{\mathrm{s}}$ )および水平部の 層平均水理量 $\left(\mathrm{h}_{\mathrm{h}}, \mathrm{U}_{\mathrm{h}}, \varepsilon_{\mathrm{h}}\right)$ は, それぞれ測定で得ら れた密度と流速分布に基づきモーメント法で求め, 斜面部下端での希釈混合率 $\gamma_{\mathrm{s}}$ と水平部での総混合率 $\gamma_{\mathrm{t}}$ を算定した(以下，モーメント法で求めた層厚に基 づく界面を「M界面」という).

\section{3. 実験結果と考察}

図-2は，フェンスの設置水深 $\mathrm{z}_{\mathrm{f}} / \mathrm{h}_{\mathrm{c}}$ を変化させた時 の定常状態での流況(CASE A)を示したものである.

これより，(1) CASE A-1とA-2の比較より，設置水 深を自然な潜り込み状態での界面よりやや上方にす ると, 潜入点が下流側に移動することや, CASE A2ではフェンス下端と流動層との間から池水がフェ ンス上流側に流入し，その上流側では流入水と池水 とが混合した状態となること，(2)設置水深を界面位 置としたCASE A-3では，僅かな池水の流入がある こと，(3)設置水深を界面からやや下方にしたCASE A-4では, 池水の流入がなくなり流入水がフェンス 上流側に滞留していくこと，(4)設置水深をさらに下 げたCASE A-5では, フェンス上流側に貯留された 流入水が池水側に噴出してくるため, フェンス下流 側で強い希釈混合が引き起こされること, などのこ とが観測された。

また，表-1中のCASE Aの水平部の無次元層厚 $\mathrm{h}_{\mathrm{h}} / \mathrm{h}_{\mathrm{c}}$ と総混合率 $\gamma_{\mathrm{t}}$ の結果より，(1)フェンスを設置す ると, これらのいずれも低下しており, 設置効果が 認められること, (2) 自然な潜り込み状態(CASE A1)での界面よりやや上方(CASE A-2)や大幅に下方 (CASE A-5)に設置した場合では，それぞれフェンス 


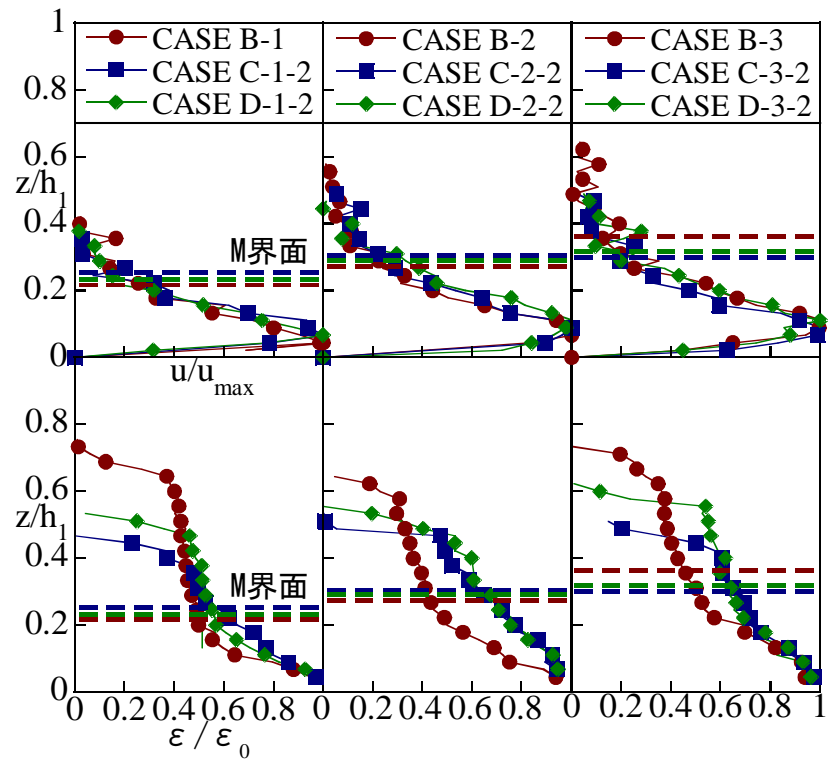

図-6 斜面下端(左) と水平部(右)での流速分布と相対密度差分布
上流側や下流側で希釈混合が生じるので，大きな効 果は期待できないこと，(3)界面(CASE A-3)あるいは 界面やや下方(CASE A-4)に設置すればフェンスの設 置効果が認められ，後者の方がより効果が大きいこ と，などの示唆が得られる。

図-3は，界面と $\mathrm{M}$ 界面，界面と密度界面の関係を プロットしたものである。これらより目視界面はM 界面の1.2倍程度，密度界面と同程度であることが 確認でき，その大きさは相互に関係付けられる。

図-4と図-5は，設置水深を界面あるいは界面下方 $\left(0.5 \mathrm{~h}_{\mathrm{c}}\right.$ 程度 $)$ にした状態で，流入内部Froude数 $\mathrm{F}_{0}$ と フェンス設置位置 $\mathrm{x}_{\mathrm{f}} / \mathrm{L}$ 変化させたときに，フェン スが設置されていない場合とされている場合とで $\mathrm{h}_{\mathrm{h}} / \mathrm{h}_{\mathrm{c}}$ と $\gamma_{\mathrm{t}}$ がどのように異なってくるのかについて調 ベたものである。両図中で○はフェンス下端を $\Delta / \mathrm{h}_{\mathrm{c}}=-0.5$ (界面下方)に, $\square$ は $\Delta / \mathrm{h}_{\mathrm{c}}=0$ (界面位置)に設 定した場合を示しており，記号に付いたバーは両者 に対応する值の幅を示している。また，記号に付け た色は $\mathrm{F}_{0}$ の違いを示している。これより，(1) フェ ンスを設置することで， $\mathrm{h}_{\mathrm{h}} / \mathrm{h}_{\mathrm{c}}$ と $\gamma_{\mathrm{t}}$ のいずれも小さく なり，設置位置を斜面部の下流側にした場合や $\mathrm{F}_{0}$ が 大きい場合の方がより小さくなること， $\mathrm{x}_{\mathrm{f}} / \mathrm{L}=0.450$ では， $\mathrm{F}_{0}$ にかかわらず，設置水深を界面 とした方が， $\mathrm{h}_{\mathrm{h}} / \mathrm{h}_{\mathrm{c}}$ と $\gamma_{\mathrm{t}}$ のいずれも界面下方とした場 合より小さいが， $\mathrm{x}_{\mathrm{f}} / \mathrm{L}=0.675$ ではその逆となってい ること，などが確認される。(1)のようになるのは, いずれも潜入密度流が斜面部を流れ下る距離が短く なるために，流入水と池水との希釈混合が弱まるた めであり，(2)は， $\mathrm{x}_{\mathrm{f}} / \mathrm{L}=0.450$ では設置水深が深すぎ たため，図-2のCASE A-5で見たような噴出が発生 しているためであると考えられる。

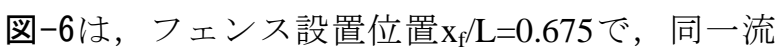
入条件下での斜面下端と水平部での流速と相対密度 差を示したものである。図中の破線はM界面の位置 を示している。なお，破線と各分布に付けた色で各 ケースを対応させている。これより，いずれの断面

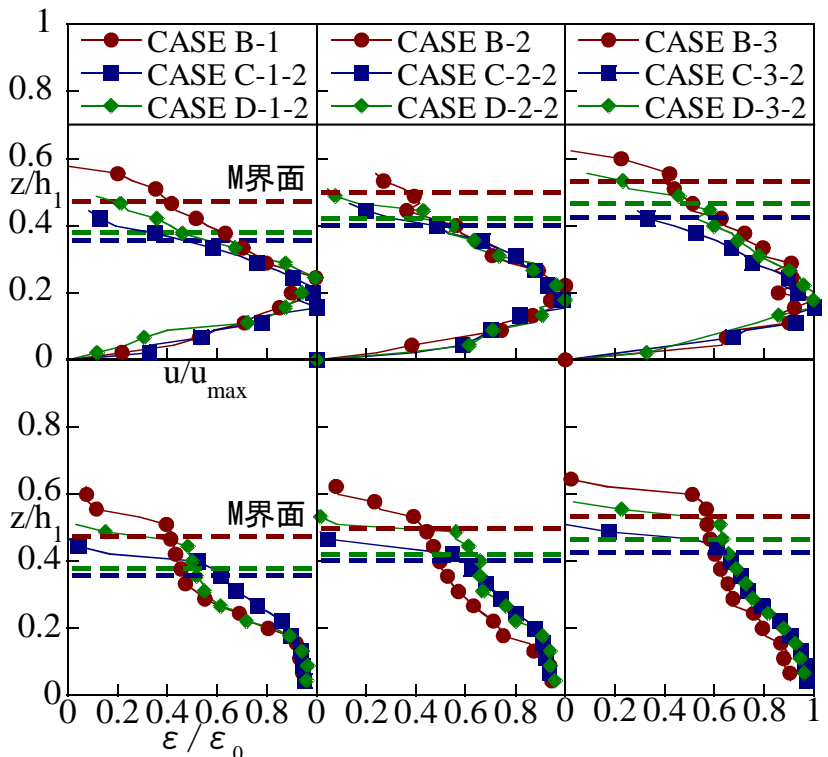

においても，フェンスを設置した場合には，流動層 上方における拡散と流速の低下が見られ，流速およ び相対密度差分布の一様化が図られていることが確 認できる。また，そのような傾向は流入条件が変化 しても，同様であることもわかる。

以上より，(1)フェンスの設置水深としては，図-4 と図-5から明らかなように，水平部の層厚と総混合 率を最小にでき，図-6のCASE Cのように相対密度 差分布の一様化が図られることから，自然な潜り込 み状態での界面のやや下方に設定すれば，最も効果 的である。しかしながら，深く入れすぎると，図-2 のCASE A-5のように逆効果になる可能性もあるこ とや，実水域では流量や水位の変動があることなど を勘案すると，フェンスを界面位置に設置すれば， 平均的に見て水域への栄養塩の拡散を抑制するとと もに, 流入水をより深く潜り込ませる効果が期待で きること，(2)設置位置としては，斜面部のより下流 側にした方がより効果的であるが，フェンスには藻 類の水域全体への拡がり防止という重要な機能があ るので，状況に応じて設置位置を設定する必要があ ること，などが示唆されている。なお，密度分布が 現地観測によりわかっている場合は，フェンス設置 水深を密度界面位置に，また斜面が一定勾配の単純 な形状の貯水池における潜入密度流であれば，自然 な潜り込み状態での潜入点と界面形状はある程度予 測可能であるので7),8),11)，M界面に基づく界面形状 を予測した上で，フェンスの設置水深をその1.2倍 程度上方に設定すれば良いと考えられる。

\section{4. 数值シミュレーション}

以上の実験結果より，効果的な流動制御が行える フェンス設置方法ついて指標を得ることができたの で，以下ではSMM-BIF-CGモデル(numerical model with Simplified MAC and MUSCL method for Buoyancy Induced Flows based on Collocated grid system in 


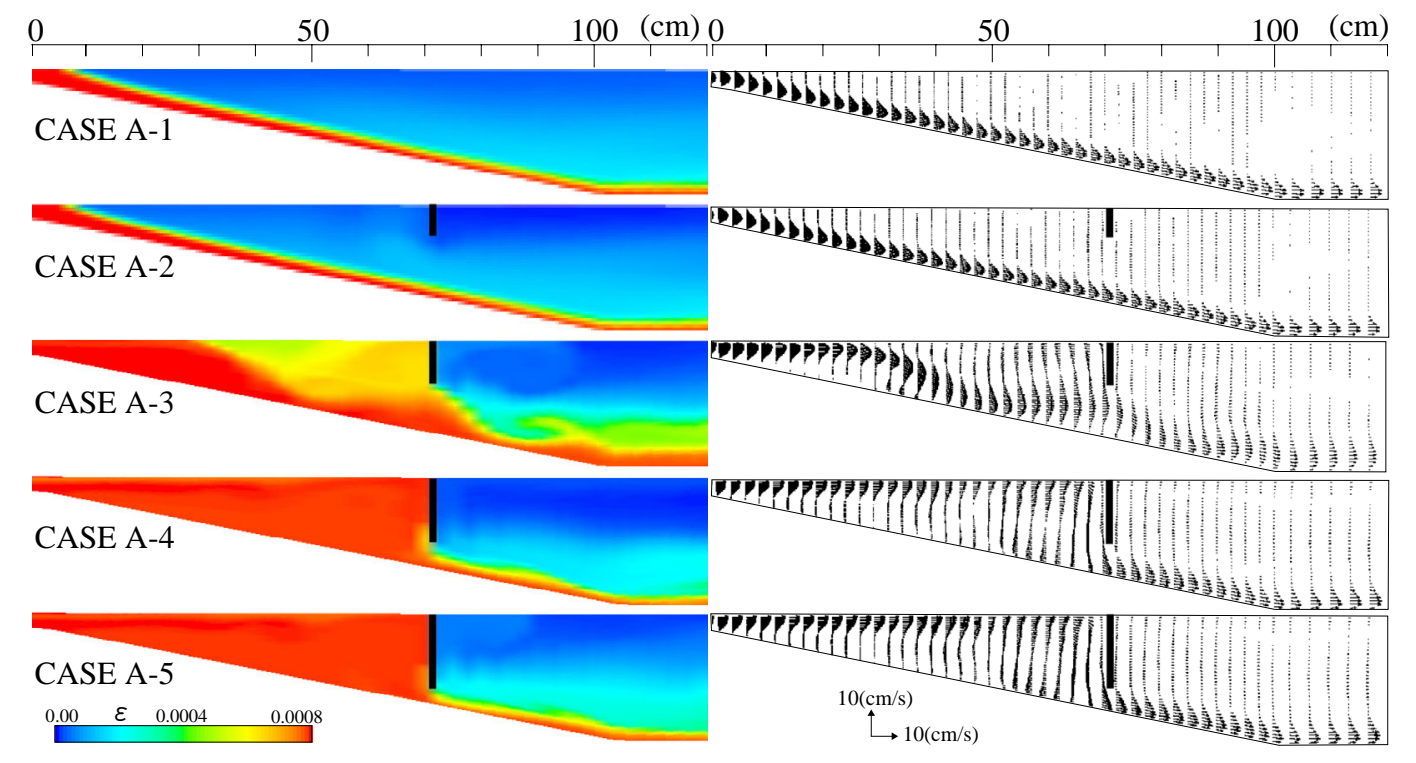

図-7 数值解析によるCASE Aの再現 (左 : 等相対密度差, 右 : 流速ベクトル)
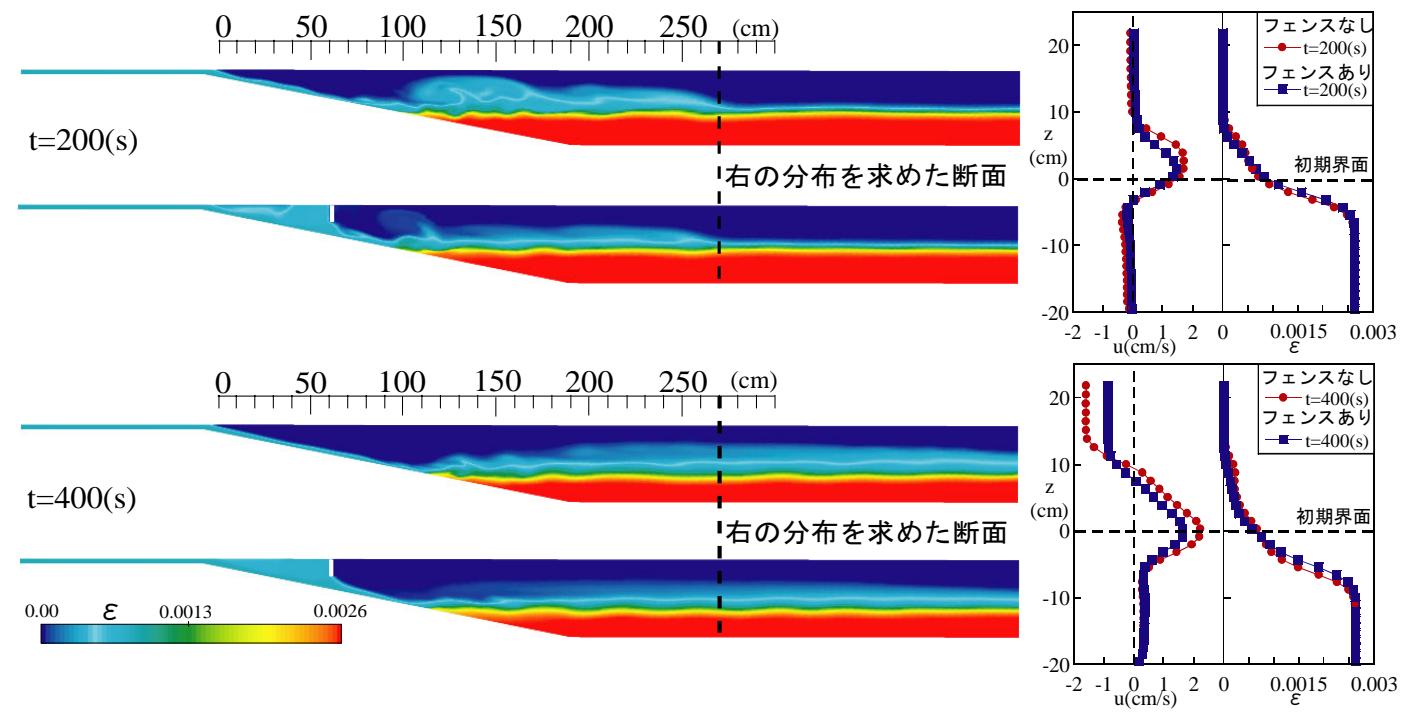

図-8 成層型貯水池におけるフェンスなし(上)，あり(下)の状況での等相対密度差および流速・相対密度差分布

General-coordinate grid system) ${ }^{22)}$ を用い, (1) CASE A を対象として，フェンスによる潜入密度流の流動制 御の再現を試みるとともに，(2)数值実験に基づき， 成層型貯水池を対象として潜入から中層密度流とし て躍層に貫入する状況でのフェンスの設置効果につ いて調べる。なお，本モデルの再現精度については， 緩勾配あるいは急勾配を有する閉鎖性水域での自然 な潜り込みを対象として, 流入内部Froude数を変化 させた数值解析と実験結果との比較より, 潜入点, 流速・密度分布および混合率 $\gamma$ について詳しく調べ てある ${ }^{22)}$.

計算領域は，流下方向と鉛直方向にそれぞれ 181 と36に分割した。水域の形状は，(1)CASE Aを対象 とした再現計算では実験と同じとし，(2)成層型貯水 池を対象とした数值実験では，斜面部の勾配は実験 と同じで，上層と下層の水深をそれぞれ $21 \mathrm{~cm}$ と $20 \mathrm{~cm}$ と，下層水の相対密度差は流入水を基準とし て0.0026とした。なお，フェンスの設置水深は界面
位置としている.

計算の初期条件には, 全ての計算領域で $\mathrm{u}=\mathrm{v}=0$ と $\varepsilon=0$ を与えた.境界条件は, 側壁, 底面およびフェ ンスには， $\mathrm{u}=\mathrm{v}=0$ (non-slip 条件)， $\partial \Phi / \partial \mathrm{n}_{1}=0$ ， $\partial \varepsilon / \partial \mathrm{n}_{1}=0$ を, 水表面には, $\partial \mathrm{u} / \partial \mathrm{n}_{1}=0, \mathrm{v}=0$ (slip 条件), $\Phi=0, \partial \varepsilon / \partial \mathrm{n}_{1}=0$ を与えた. 上流端の流入条件には, $\varepsilon=\varepsilon_{0}, \mathrm{u}=\mathrm{q}_{0} / \mathrm{h}_{0}, \mathrm{v}=0$ を与え, その值はCASE Aと同じ とした。下流端の条件は, 自由流出条件 $\partial \mathrm{u} / \partial \mathrm{n}_{2}=0$,

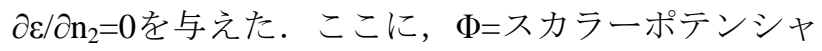
ル, $\mathrm{n}_{1}=$ 水表面, 側壁および底面に垂直な方向, $\mathrm{n}_{2}=$ 流出境界に垂直な方向である.

図-7は，計算より得られたCASE Aの相対密度差 のコンターと流速ベクトルを示したものである.

図-2との比較より，(1) CASE A-1では全体的な流況, 例えば底面が急斜面から水平に変化するため, 内部 跳水により層厚が増加している様子, CASE A-2で はフェンス設置の影響を受け, 下層が盛り上がって いる様子，(2)CASE A-3では池水がフェンス下端か 
らフェンス上流側に流入し，その上流側で循環流や 希釈混合が生じている様子, (3)CASE A-4では, フェンス上流側への池水の流入はなく，その上流側 に流入水が貯留され大きな循環流が生じていること や，その下流側では流動層厚がCASE A-1 より低下 している様子，(4) CASE A-5では，フェンス下端と 斜面との間から大きな流速を持って噴出してくるた め，フェンス下流側で強い希釈混合が起こっている こと，などの実験結果で見た流動状況が確認できる。 図-8は, 流入水が潜入した後に中層密度流として 躍層に貫入する場合の数值実験結果を示したもので ある. 図中には流速および相対密度差分布も示され ている．これより，フェンスを設置することで，(1) 潜入後の下層密度流の流速が減少し, 流入水が界面 に到達した時に生じるフロントの舞上がりが抑制さ れていること，(2) 躍層と斜面部下端での内部跳水 が弱められており, 内部跳水の連行による逆流が抑 制されていること，(3)上層への流入水の拡散が抑制 されていること，などのことが認められ，この場合 もフェンスを界面位置に設置することで，流動制御 の効果が得られることがわかる。

\section{5. 結論}

実験研究より, (1)フェンスの設置水深は, 実水域 での流量や水位の変動等があることを勘案し，自然 な潜り込み状態での界面位置に設置すれば，設置効 果が期待できること，(2)設置位置は，斜面部の下流 側にした方がより効果的であること，などが示唆さ れた。

数值解析より, (1)SMM-BIF-CG modelは, 混合型 貯水池のみならず, 成層型貯水池におけるフェンス による潜入密度流の流動制御の効果や影響を検討で きること，などがわかった。

今後は，SMM-BIF-CGモデルを3次元モデルへ発 展させるとともに, 現地観測結果との比較検討を試 みる予定である。また，参考文献22)で示されてい るように，本モデルの再現精度には改善の余地があ るので，これも今後の課題である.

\section{参考文献}

1) 久保直也ら：風屋貯水池における淡水赤潮現象と貯 水池環境，大ダム, No. 126, pp. 18-25, 1988.

2) 畑 幸彦: 永瀬ダム湖（高知県）の淡水赤潮, 水質 污濁研究，Vol. 14，No. 5, pp. 25-29, 1991.

3) 中本信忠: 神流湖の淡水赤潮, 水質污濁研究, Vol. 14, No. 5, pp. 13-17, 1991.

4) 山田正人, 宗宮功, 小野芳朗, 小林尚礼: ダム貯水 池におけるPeridinium淡水赤潮の集積機構の評価, 水 環境学会誌，第18巻，第10号，pp. 775-783，1995.

5) 松尾直規, 山田正人, 宗宮功: 貯水地上流端におけ る流動特性と淡水赤潮現象との関係, 水工学論文集, 第40巻, pp. 575-581， 1996.

6) 天野邦彦, 田中康泰, 鈴木宏明, 安田佳哉: 貯水池 末端における持続的な淡水赤潮に関寸る研究, 水工 学論文集, 第44巻, pp.1083-1088, 2000.
7) 秋山壽一郎, A.K.ジャ, 山下直樹, 浦 勝 : ダム貯 水池上流端での富栄養化対策を目的とした遮蔽膜に よる潜入密度流の制御, 水工学論文集, 第 46 巻, pp. 1013-1018, 2002.

8) 秋山壽一郎, 西 恭太, 浦 勝 : 潜入密度流の流動 特性とフェンス工による流動制御, 水工学論文集, 第 47巻, pp. 1177-1282, 2003.

9) Singh, B. \& Shah, C.R. : Plunging phenomena of density currents in reservoirs, LaHouille Blanche, Vol.26, No.1, pp.59-64,1971.

10) Savage, S.B. \& Brimberg, J.: Analysis of plunging phenomena in water reservoirs, J. of Hydraulic Research, Vol.13, No.2, pp.187-204, 1975.

11) 福岡捷二, 福嶋祐介, 中村健一：2 次元貯水池潜入 密度流の潜り込み水深と界面形状, 土木学会論文報 告集，第302号，pp. 55-65, 1980.

12) Hauenstein, W. \& Dracos, T.H. :Investigation of plunging density currents generated by inflows in lakes, J. of Hydraulic Research, Vol.22, No.3, pp.157-179, 1984.

13) Akiyama, J. \& Stefan, H.G. : Plunging flow into a reservoir: theory, J. of Hydraulic Engineering, ASCE, Vol.110, HY.4, pp.484-498, 1984.

14) 有田正光, 塚原千明：貯水池密度流の潜り点の水理 条件に関する実験的研究，ながれ，第 15 巻，pp. 409416, 1996.

15) Lee, H.Y \& Yu, W.S.: Experimental study on reservoir turbidity current, J. of Hydraulic Engineering, ASCE, Vol.123, No.6, pp.520-528, 1997.

16) Elder, R.A. \& Wunderlich, W.O.: Inflow dernsity currents in TVD reservoirs, Int'l Symp. Stratified Flows, IAHR/ASCE, Novosibirks, USSR, pp.221-236, 1972.

17) Hebbert, B. et al.: Collie river underflow into the Wellington reservoir, J. of Hydraulic Engineering, ASCE, Vol.105, HY.5, pp.533-545, 1979.

18) Ford, D.F. et al.: Density inflows to Degray lake, Arkansas, Proc. of Second Int'l Symposium on Stratified Flows, Trondheim, Norway, pp.977-987, 1980.

19) Farrell, G.J. \& Stefan, H.G.: Mathematical modeling of plunging reservoir flows, J. of Hydraulic Research, Vol.26, No.5, pp.525-537, 1988.

20) Bournet, P.E., Dartus,D., Tassin, B. \& Vincon-Leite, B.: Numerical investigation of plunging density current, $J$. of Hydraulic Engineering, ASCE, Vol.125, No.6, pp.584-594, 1999.

21) Dallimore, C.J., Imberger,J.,Hodges, B.R.:Modeling a plunging underflow, J. of Hydraulic Engineering, ASCE, Nov., pp.1068-1075, 2004.

22) 重枝未玲, 秋山壽一郎：一般座標コロケート格子を 用いた鉛直 2 次元モデルによる潜入密度流の数值解析, 水工学論文集，第49巻，pp. 1159-1164, 2005.

23）秋山壽一郎, 片山哲幸, 西 恭太, 土居正明 : 混合 型・成層型貯水地での潜入密度流の水理特性につい て, 水工学論文集, 第48巻, pp. 1375-1380, 2004.

24）秋山壽一郎：流入型密度流の水理特性とその予測, 湖沼, 貯水地の管理に向けた富栄養化現象に関する 学術研究のとりまとめ, 土木学会水理委員会環境水 理部会, pp.69-167, 2000.

(2005. 9. 30受付) 